Konieczny Magdalena. Quality of life of women after mastectomy. Journal of Education, Health and Sport. 2022;12(1):21-33. eISSN 2391-8306. DOI http://dx.doi.org/10.12775/JEHS.2022.12.01.002

https://apcz.umk.pl/JEHS/article/view/JEHS.2022.12.01.002

https://zenodo.org/record/5819166

The journal has had 40 points in Ministry of Education and Science of Poland parametric evaluation. Annex to the announcement of the Minister of Education and Science of December 1, 2021. No. 32343. Has a Journal's Unique Identifier: 201159. Scientific disciplines assigned: Physical Culture Sciences (Field of Medical sciences and health sciences); Health Sciences (Field of Medical Sciences and Health Science).

Punkty Ministerialne z 2019 - aktualny rok 40 punktów. Zalącznik do komunikatu Ministra Edukacji i Nauki z dnia 1 grudnia 2021 r. Lp. 32343. Posiada Unikatowy Identyfikator Czasopisma: 201159. Przypisane dyscypliny naukowe:Nauki o kulturze fizycznej (Dziedzina nauk medycznych i nauk o zdrowiu); Nauki o zdrowiu (Dziedzina nauk medycznych i nauk o zdrowiu).

(1) The Authors 2022;

This article is published with open access at Licensee Open Journal Systems of Nicolaus Copernicus University in Torun, Poland

Open Access. This article is distributed under the terms of the Creative Commons Attribution Noncommercial License which permits any noncommercial use, distribution, and reproduction in any medium, provided the original author (s) and source are credited. This is an open access article licensed under the terms of the Creative Commons Attribution Non commercial license Share alike.

(http://creativecommonsorg/icense/by-nc-s/40/) which permits The authors declare that there is no conflict of interests regarding the publication of this paper.

Received: 15.12.2021. Revised: 25.12.2021. Accepted: 05.01.2022.

Jakość życia kobiet po mastektomii

\title{
Quality of life of women after mastectomy
}

\section{Magdalena Konieczny}

Magdalena Konieczny, e-mail: mkonieczny@up-sanok.edu.pl, ORCID - 0000-0001-60898869

Afiliacja: Instytut Medyczny, Uczelnia Państwowa im. Jana Grodka w Sanoku, Polska Affiliation: The Jan Grodek State Universityin Sanok, Medical Institute

\section{Streszczenie}

Wprowadzenie. Wystąpienie choroby nowotworowej piersi u kobiety jest kryzysowym wydarzeniem, które wiąże się z koniecznością wdrożenia długotrwałego i obciążającego leczenia. Jakość życia kobiet będących w takiej sytuacji ulega zmianie. Z tego względu bardzo ważna jest ocena kondycji psychicznej, stanu emocjonalnego kobiet oraz stopnia zaakceptowania przez nie nowej sytuacji, a także rozpoznanie oczekiwań i potrzeb pacjentek $\mathrm{z}$ rakiem piersi.

Celem pracy była ocena jakości życia kobiet $\mathrm{z}$ rozpoznanym rakiem piersi, u których przeprowadzono zabieg mastektomii.

Material i metody. Badania przeprowadzono w Podkarpackim Ośrodku Onkologicznym w Brzozowie wśród 231 kobiet z rakiem piersi, u których zastosowano leczenie chirurgiczne (mastektomia). Badania przeprowadzono za pomocą sondażu diagnostycznego przy wykorzystaniu autorskiego kwestionariusza ankiety składającego się z 39 pytań. Na przeprowadzanie badań uzyskano zgodę Dyrektora Szpitala oraz Komisji Bioetycznej.

Wyniki. Stan emocjonalny badanych został oceniony jako zły (26,9\%) lub raczej zły $(21,3 \%)$, a jedna trzecia respondentek odczuwała smutek i apatię (bardzo często - 26,9\%; codziennie$6,8 \%)$. 
Kobiety najczęściej obawiały się przerzutów nowotworu (47,2\%), nawrotu choroby $(33,3 \%)$ oraz wystąpienia bólu (29,0\%). Jako ograniczenia życia codziennego wynikające z choroby kobiety w większości uznawały zakłócenia w życiu rodzinnym i towarzyskim $(38,3 \%)$ oraz zmniejszenie efektywności pracy (30,6\%).

Wnioski. Kobiety posiadały obniżoną jakość życia, w szczególności w sferze emocjonalnej, życia rodzinnego i zawodowego. Respondentki z rakiem piersi oczekują większego wsparcia ze strony lekarza, co może stanowić podstawę do wprowadzenia zmian w kształceniu studentów medycyny i prowadzeniu szkolenia podyplomowego w tym zakresie.

Słowa kluczowe: rak piersi, jakość życia, mastektomia, życie rodzinne i zawodowe

\begin{abstract}
Introduction. The occurrence of breast cancer in a woman is a crisis event that requires the implementation of long-term and burdensome treatment. The quality of life of women in such a situation is changing. For this reason, it is very important to assess the mental condition, emotional state of women and the degree of their acceptance of the new situation, as well as to recognize the expectations and needs of breast cancer patients.
\end{abstract}

The goal of the work was the assessment of the quality of life of women with diagnosed breast cancer who underwent mastectomy.

Material and methods. The study was conducted at the Podkarpackie Oncology Center in Brzozów among 231 women with breast cancer, in whomwho were treated with surgery (mastectomy). The research was carried out by means of a diagnostic survey using the proprietary questionnaire consisting of 39 questions. The research was approved by the Hospital Director and the Bioethics Committee.

Results. The emotional state of the respondents was assessed as bad (26.9\%) or rather bad (21.3\%), and one third of the respondents felt sad and apathy (very often - 26.9\%; daily $6.8 \%)$. Women most often feared tumor metastasis $(47.2 \%)$, disease recurrence $(33.3 \%)$ and pain $(29.0 \%)$. As limitations in everyday life resulting from the disease, the majority of women considered disruptions in family life and social life (38.3) as well as reduced work efficiency (30.6\%).

Conclusions. Women had a reduced quality of life, especially in the emotional, family and professional spheres. Respondents with breast cancer expect greater support from the doctor, which may constitute the basis for introducing changes in the education of medical students and conducting postgraduate training in this field.

Keywords: breast cancer, quality of life, mastectomy, family and work life 
Wstęp. Rak piersi jest najczęstszym nowotworem złośliwym kobiet nie tylko w Polsce, ale również w większości krajów na świecie. W skali globalnej występowanie raka piersi ocenia się jako jedną z najważniejszych chorób nowotworowych dotyczących kobiet. Jeszcze w 2002 roku rozpoznano na świecie ponad 1150000 zachorowań, a obecnie najbardziej aktualne dane wskazują już na prawie 230000 nowych rozpoznań raka piersi rocznie [1, 2 ]. Ze względu na stały wzrost liczby zachorowań rak piersi jest również dużym zagrożeniem dla kobiet w Polsce i jest najczęściej diagnozowaną chorobą nowotworową wśród Polek. Zachorowalność na ten rodzaj nowotworu wzrosła w ciągu ostatnich 30 lat ponad dwukrotnie [3]. W 2000 roku stwierdzono 11853 przypadków raka piersi, a w 2020 roku rozpoznano 24644 zachorowań z powodu tego nowotworu [1]. W strukturze rejestrowanych zachorowań na nowotwory złośliwe kobiet, choroba ta najczęściej dotyczy pacjentek w przedziale wieku 50-69 lat. W tej grupie odnotowuje się ok. 60\% wszystkich zachorowań. Wyższy wzrost zachorowalności w grupie wieku 50-69 lat w porównaniu z kobietami powyżej 70 roku życia, stwierdza się od kilkunastu lat i różnica ta pogłębia się [4].

Wystąpienie choroby nowotworowej piersi u kobiety jest kryzysowym i stresującym wydarzeniem zarówno dla niej, jak i dla jej rodziny. Rozpoznanie raka piersi wiąże się z koniecznością wdrożenia długotrwałego i obciążającego leczenia. Terapia onkologiczna z reguły jest agresywna i jako taka jest postrzegana, co dodatkowo powoduje u pacjentek strach z powodu jej zastosowania i przewidywanych skutków leczenia. Wraz z początkiem leczenia $\mathrm{z}$ powodu nowotworu piersi u kobiet obserwuje się zmiany zachodzące $\mathrm{w}$ ich psychice. Kryzys psychologiczny ma związek z niejasną prognozą. Kobiety okazują lęk przed kalectwem i śmiercią, z drugiej strony przed rozbiciem rodziny i byciem porzuconą. Często towarzyszy im również gniew, agresja i obniżony nastrój [5-7]. U kobiet poddanych radykalnemu leczeniu chirurgicznemu występuje dodatkowo poczucie obniżenia własnej wartości. Wskutek dużego urazu i lęku psychicznego spowodowanego całkowitą lub częściową utratą piersi może wystąpić „kompleks połowy kobiety/ciała”. Zachwiana zostaje samoocena w aspekcie społecznym. Kobiety czują się niepełnowartościowe z powodu obniżenia poczucia kobiecości i braku atrybutu macierzyństwa [8-10]. Ocena kondycji psychicznej, stanu emocjonalnego kobiet czy zaakceptowania przez nie nowych warunków zdrowotnych może zostać wykonana poprzez badanie jakości ich życia (QoL). W przypadku raka piersi pierwsze badania QoL wykonano w latach 60-tych XX wieku, a ich wyniki po raz pierwszy wykorzystano podczas oceny skutków leczenia [11]. W obliczu niepokojących prognoz dotyczących wzrostu liczby zachorowań kobiet na raka piersi w ciągu najbliższych lat, bardzo duże znaczenie zyskuje wiedza na temat predyktorów jakości życia pacjentek z tym rodzajem nowotworu. Stało się to podstawą do podjęcia badań w zakresie oceny jakości życia kobiet z rozpoznaniem raka piersi.

Celem pracy była ocena jakości życia kobiet z rozpoznanym rakiem piersi.

Materiały i metody. Badania przeprowadzono w Szpitalu Specjalistycznym, Podkarpackim Ośrodku Onkologicznym im. Ks. B. Markiewicza w Brzozowie. Badaniem objęto grupę 231 kobiet $\mathrm{z}$ histopatologicznie potwierdzonym nowotworem piersi. U kobiet włączonych do badań zastosowano leczenie chirurgiczne - mastektomię. Przed przystąpieniem do badań wszystkie pacjentki zostały poinformowane o jego celu, zapewnione o poufności, anonimowości i dobrowolności udziału w badaniach. Ponadto kobiety zostały poinformowane o możliwości rezygnacji z badania na każdym jego etapie. 
Do badań włączono pacjentki, u których potwierdzono histopatologicznie raka gruczołu piersiowego, wyraziły zgodę na udział w badaniu oraz były leczone chirurgicznie (mastektomia) w Podkarpackim Ośrodku Onkologicznym w Brzozowie. Kryteriami dyskwalifikującymi pacjentki do udziału w badaniach były następujące czynniki: występowanie innego niż rak piersi nowotworu i leczonego w okresie ostatnich 5 lat, leczenie paliatywne oraz odmowa/brak zgody pacjentki na udział w badaniu. Na przeprowadzenie badań uzyskano zgodę dyrektora Szpitala Specjalistycznego, Podkarpackiego Ośrodka Onkologicznego im. Ks. B. Markiewicza w Brzozowie. Projekt uzyskał również pozytywną opinię Komisji Bioetycznej.

Badania przeprowadzono za pomocą sondażu diagnostycznego przy wykorzystaniu autorskiego kwestionariusza ankiety, składającego się z 39 pytań. Kwestionariusz ankiety składał $\mathrm{z}$ trzech części. Część pierwsza zawierała pytania dotyczące charakterystyki społeczno-demograficznej badanej grupy: wieku, miejsca zamieszkania, stanu cywilnego, zawodu, wykształcenia, sytuacji finansowej oraz liczby posiadanych dzieci. Część druga dotyczyła informacji na temat okoliczności wykrycia nowotworu, określenia czasu diagnozy i wdrożenia terapii, stopnia zaawansowania raka, jego typu oraz zastosowanego leczenia. Natomiast część trzecia była złożona z pytań dotyczących subiektywnej oceny jakości życia kobiet $\mathrm{z}$ rakiem piersi. W niniejszej pracy wykorzystano informacje otrzymane $\mathrm{z}$ części pierwszej i trzeciej ankiety.

Wyniki. Największą grupę stanowiły respondentki powyżej 60 roku życia $(29,4 \%)$, natomiast najmniejszą będące w przedziale wieku 20-30 lat (3,7\%). Kobiety w wieku 31-40 lat, 41-50 lat oraz 51-60 lat stanowiły odpowiednio: 20,6\%; 21,6\% oraz 24,7\%. Badane respondentki były $\mathrm{W}$ większości mieszkankami miast $(54,3 \%)$. W badanej grupie dominowały kobiety żyjące w związku $(66,1 \%)$ oraz ze średnim $(35,2 \%)$ i wyższym wykształceniem $(33,3 \%)$. Kobiety posiadające wykształcenie podstawowe i gimnazjalne stanowiły $12,7 \%$ badanej grupy, a zasadnicze zawodowe $18,8 \%$ badanych. Najwięcej kobiet utrzymywało się z pracy w państwowym zakładzie/instytucji $(35,5 \%)$. Dla pozostałych osób źródłem utrzymania były: praca we własnym gospodarstwie $(9,6 \%)$, własna działalność gospodarcza $(8,9 \%)$, emerytura $(15,7 \%)$, renta $(20,4 \%)$ oraz inne źródło utrzymania $(9,9 \%)$. Prawie $40 \%$ badanych kobiet oceniło swoją sytuację finansową jako bardzo dobrą, natomiast 30,6\% jako dobrą, a 29,6\% jako złą. Wśród kobiet włączonych do badań najwięcej było tych, które miały dwoje dzieci $(32,7 \%)$, nieco mniej posiadało jedno $(21,3 \%)$ i troje $(13,3 \%)$ dzieci, a najmniej czworo $(8,0 \%)$ i więcej (4,9\%). Podkreślić należy, że aż prawie $1 / 5$ badanych nie posiadała dzieci.

Najwięcej respondentek oceniło swój stan emocjonalny jako zły $(26,9 \%)$ i raczej zły (21,3\%). Nieco ponad 1/5 badanych określiła swój stan emocjonalny jako raczej dobry $(20,1 \%)$, a $15,8 \%$ kobiet jako dobry. Grupa kobiet wynosząca 15,9\% nie potrafiła zdiagnozować (ocenić) swojego stanu emocjonalnego (ryc. 1). Podkreślić należy, że 26,9\% badanych bardzo często odczuwała smutek i apatię, a u 6,8\% kobiet emocje te pojawiały się codziennie (ryc.2). 


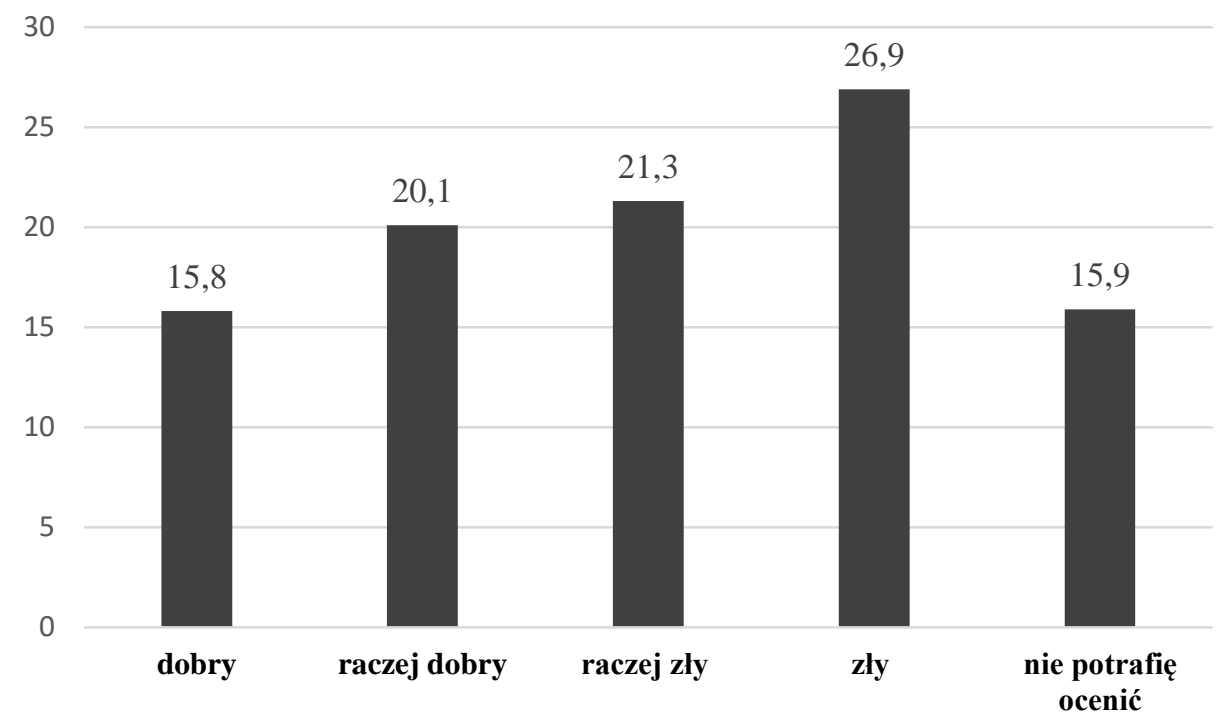

Ryc. 1. Stan emocjonalny kobiet z rozpoznanym nowotworem piersi.

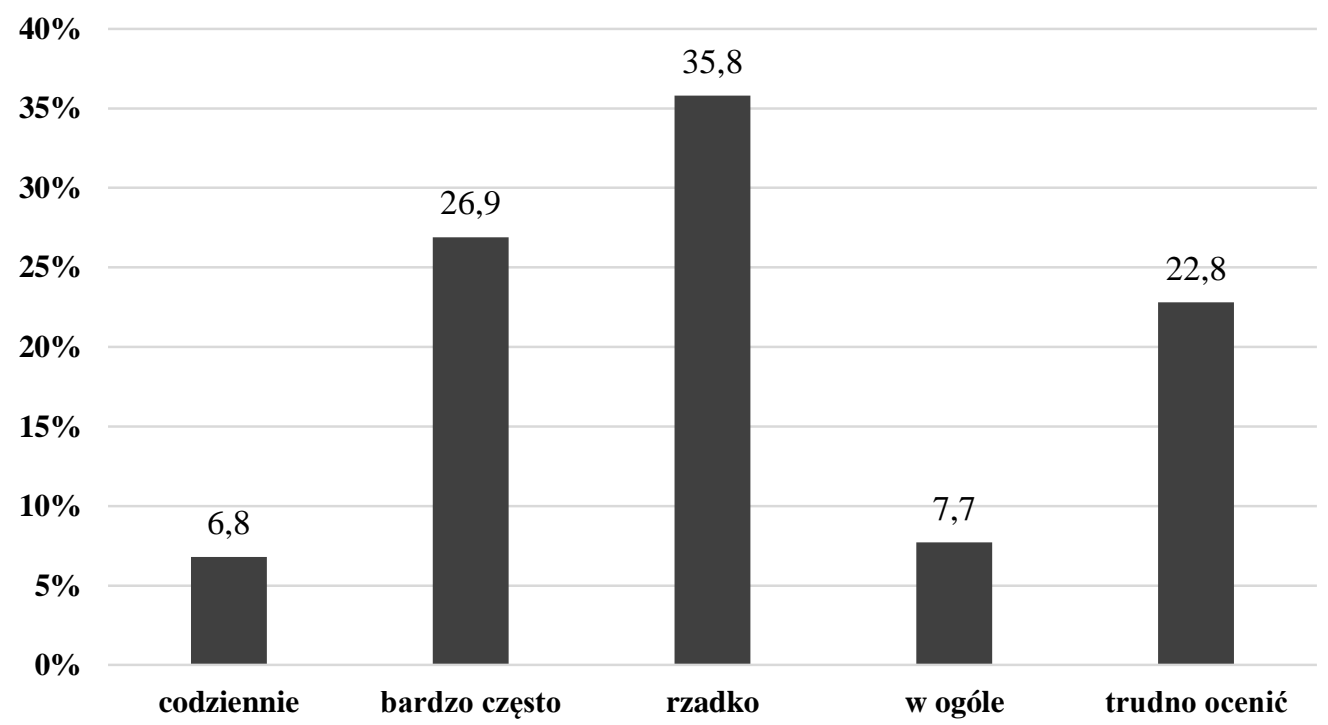

Ryc. 2. Odczuwanie smutku i apatii przez kobiety z rozpoznanym nowotworem piersi.

W związku z rozpoznanym nowotworem piersi największe obawy badanych respondentek dotyczyły przerzutów nowotworowych $(47,2 \%)$ oraz nawrotu choroby $(33,3 \%)$. Kobiety obawiały się również wystąpienia bólu (29,0\%), niesamodzielności (22,8\%), ujemnych skutków leczenia (14,2\%) czy cierpienia fizycznego (12,0\%). Ankietowane w mniejszym stopniu wskazywały na obawy w zakresie cierpienia psychicznego $(10,5 \%)$, pogorszenia sytuacji materialnej $(8,3 \%)$ i zmiany wyglądu osobistego $(7,7 \%)$ (tab.1).

Według badanych choroba nowotworowa w największym stopniu zakłóciła ich życie rodzinne i towarzyskie (38,3\%). Wystąpienie raka piersi spowodowało również zawodową destabilizację kobiet. W przypadku 30,6\% badanych choroba miała wpływ na zmniejszenie efektywności pracy, natomiast $26,2 \%$ w ogóle jej nie kontynuowało. 
Niewiele respondentek $(3,4 \%)$ wskazywało też na inne ograniczenia życia rodzinnego, takie jak: problemy z chodzeniem wskutek przerzutów do kręgosłupa, ból, brak samodzielności, mniejsza sprawność fizyczna czy noszenie peruki. Tylko 1,5\% kobiet stwierdziło, że pojawienie się choroby nie spowodowało jakichkolwiek ograniczeń w życiu codziennym (tab.1).

Tab.1. Najczęściej wymieniane obawy oraz najistotniejsze ograniczenia życia codziennego kobiet wynikające $\mathrm{z}$ wystąpienia choroby nowotworowej.

\begin{tabular}{|c|c|c|c|}
\hline Pytanie & Odpowiedź & $\mathbf{N}$ & $\%$ \\
\hline \multirow{9}{*}{$\begin{array}{l}\text { Czego najbardziej się Pani obawia? } \\
\text { (możliwość wyboru kilku odpowiedzi) }\end{array}$} & przerzutów nowotworowych & 109 & 47,2 \\
\hline & nawrotu choroby & 77 & 33,3 \\
\hline & bólu & 67 & 29,0 \\
\hline & niesamodzielności & 53 & 22,8 \\
\hline & ujemnych skutków leczenia & 32 & 14,2 \\
\hline & cierpienia fizycznego & 28 & 12,0 \\
\hline & cierpienia psychicznego & 24 & 10,5 \\
\hline & $\begin{array}{l}\text { pogorszenia sytuacji materialnej } \\
\text { rodziny }\end{array}$ & 19 & 8,3 \\
\hline & zmiany wyglądu osobistego & 18 & 7,7 \\
\hline \multirow{5}{*}{$\begin{array}{l}\text { Jakie ograniczenia życia codziennego } \\
\text { wynikające z choroby uważa Pani za } \\
\text { najistotniejsze? }\end{array}$} & $\begin{array}{l}\text { zakłócenia w życiu rodzinnym } \\
\text { i towarzyskim }\end{array}$ & 88 & 38,3 \\
\hline & brak możliwości kontynuacji pracy & 61 & 26,2 \\
\hline & zmniejszenie efektywności pracy & 71 & 30,6 \\
\hline & $\begin{array}{l}\text { inne - określone przez kobiety: } \\
\text { „problemy z chodzeniem wskutek } \\
\text { przerzutów do kregostupa, ból, brak } \\
\text { samodzielności, mniejsza sprawność } \\
\text { fizyczna czy noszenie peruki” }\end{array}$ & 8 & 3,4 \\
\hline & brak & 3 & 1,5 \\
\hline
\end{tabular}

Ankietowane kobiety oceniły również wpływ choroby na ich życie rodzinne. Prawie $1 / 4$ badanych $(23,1 \%)$ stwierdziła, że wystąpienie choroby miało negatywny wpływ na funkcjonowanie ich życia rodzinnego. 
W przypadku 28,7\% respondentek choroba nie wpłynęła na tę sferę funkcjonowania kobiet, a $30,9 \%$ kobiet nie potrafiło ocenić tej sytuacji. Podkreślenia wymaga fakt, że 17,3\% badanych stwierdziło, że rozpoznanie u nich choroby poprawiło funkcjonowanie życia rodzinnego i miało na nie pozytywny wpływ (ryc. 5).

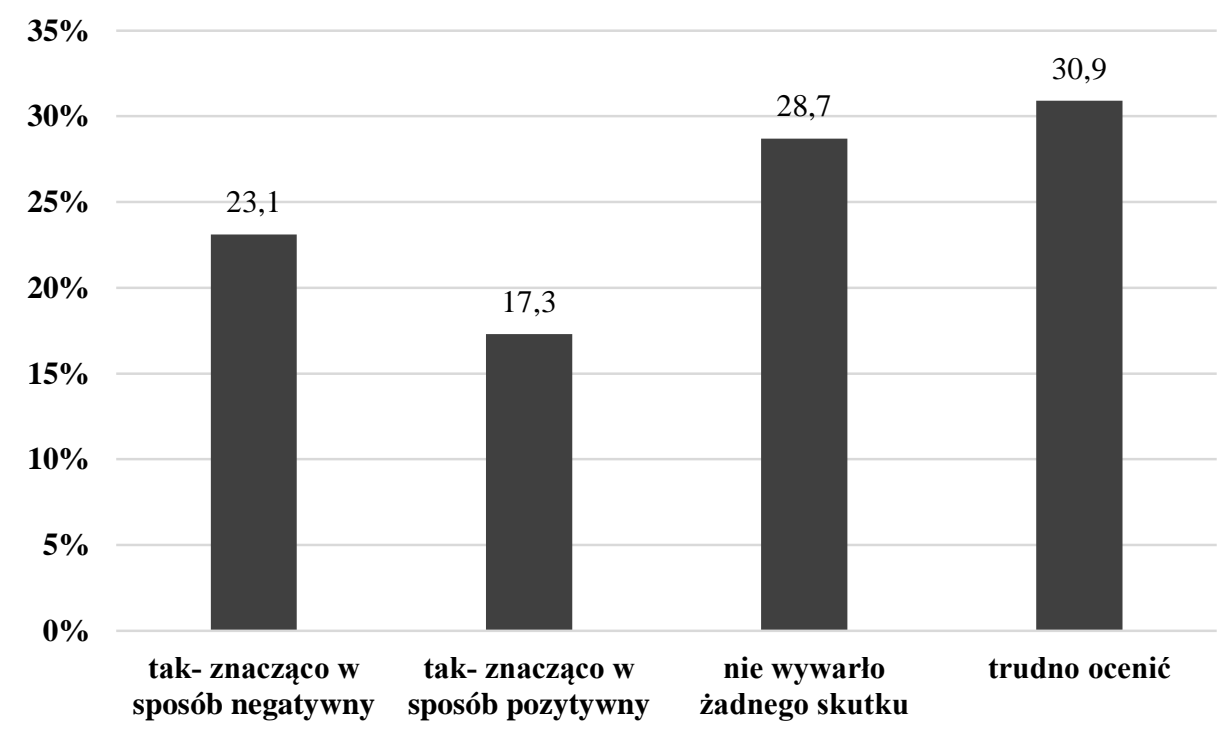

Ryc. 5. Wpływ rozpoznania choroby na życie rodzinne kobiet z nowotworem piersi

Nieco powyżej 40\% kobiet stwierdziło, że wystąpienie raka piersi zaburzyło ich funkcjonowanie $\mathrm{w}$ obszarze zawodowym, przy czym 17,9\% badanych określiło zdecydowany, a 22,8\% wątpliwy (odpowiedź „raczej tak”) wpływ choroby na życie zawodowe. Jednocześnie należy podkreślić, że 21,6\% respondentek zdecydowanie zaprzeczyła tak postawionej tezie, 21,9\% stwierdziła, że raczej choroba nie wpłynęła na ich funkcjonowanie w obszarze zawodowym, a 15,8\% badanych nie potrafiło ocenić sytuacji w tym zakresie (ryc. 6).

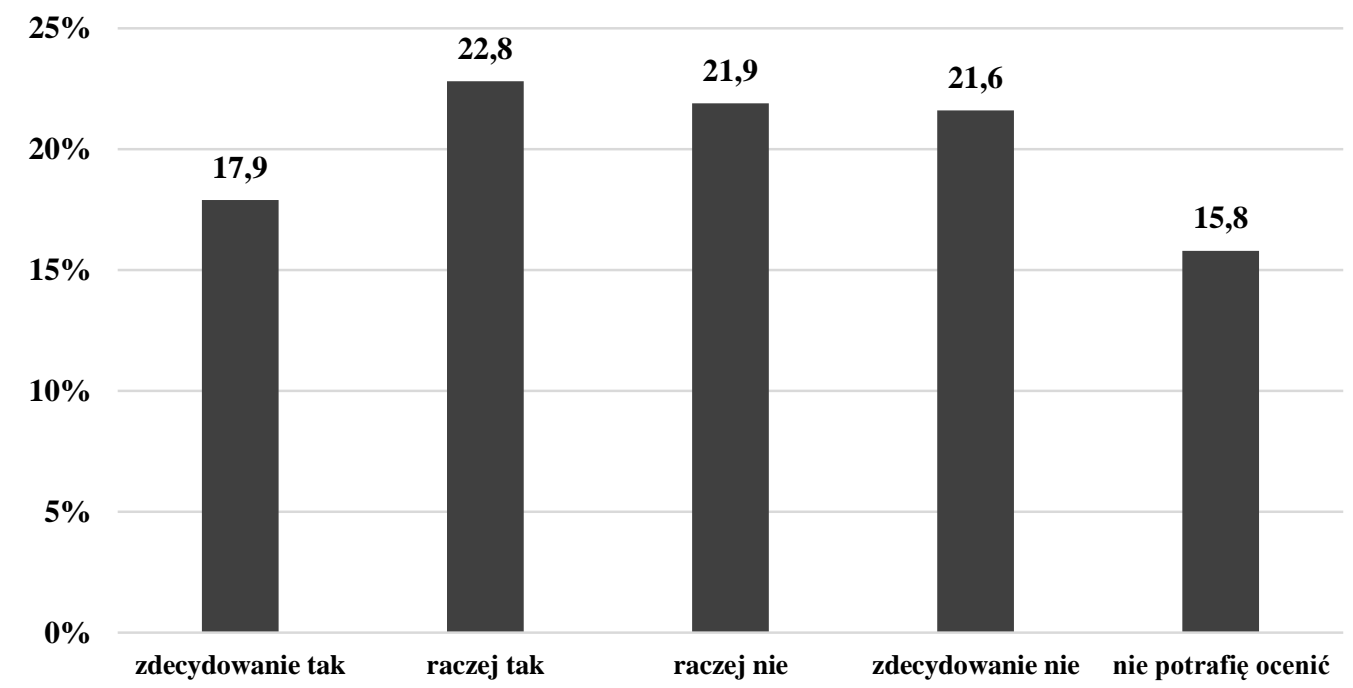

Ryc. 6. Rozpoznanie choroby nowotworowej a destabilizacja w obszarze zawodowym 
Analizując wyniki badań w zakresie oceny kontaktów społecznych badanych kobiet, należy wskazać, że dla znacznej grupy ankietowanych rak piersi był przyczyną ich ograniczenia (35,1\%), a 17,0\% respondentek w ogóle nie kontaktowało się z przyjaciółmi czy znajomymi. Pozytywnym jest fakt, że dla 38,0\% kobiet kontakty te nie uległy zmianie, a 9,9\% badanych podkreśliła znacznie większą potrzebę kontaktu niż do tej pory (ryc.7).

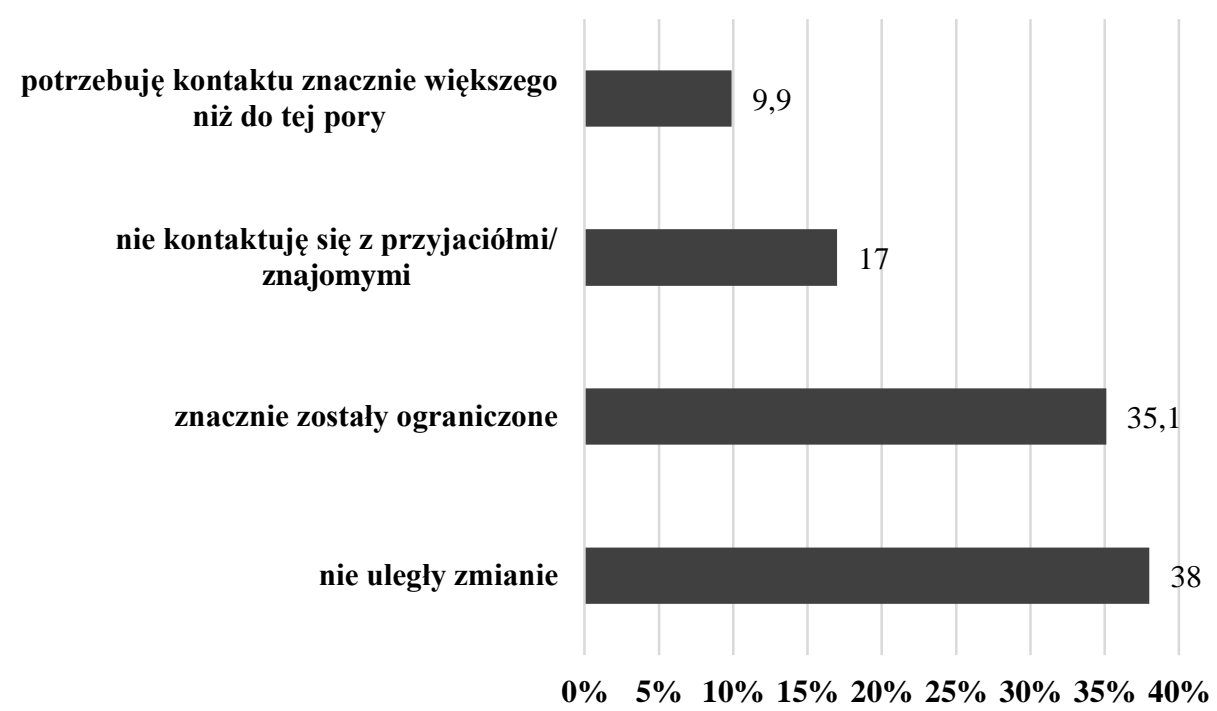

Ryc.7. Ocena kontaktów społecznych kobiet z rakiem piersi po rozpoznaniu choroby.

Ponad połowa badanych kobiet $(57,4 \%)$ wskazała, że największe wsparcie emocjonalne bezpośrednio po rozpoznaniu choroby uzyskała od rodziny. Ponadto duże znacznie w tym zakresie mieli również lekarze $(27,2 \%)$, pielęgniarki $(25,6 \%)$ oraz przyjaciele $(17,3 \%)$. Stosunkowo rzadko wsparcie takie udzielane było przez znajomych $(8,6 \%)$ oraz psychologa $(2,8 \%)$. Tylko $3 \%$ ankietowanych nie otrzymała żadnego wsparcia emocjonalnego po rozpoznaniu choroby (tab.2).

Tab. 2. Wsparcie kobiet $\mathrm{z}$ rakiem piersi - po rozpoznaniu choroby, w trakcie jej trwania oraz oczekiwania w zakresie wsparcia psychologicznego

\begin{tabular}{cccc}
\hline Pytanie & Odpowiedź & $\mathbf{N}$ & $\mathbf{\%}$ \\
\hline & rodzina & 133 & 57,4 \\
& lekarz & 63 & 27,2 \\
$\begin{array}{c}\text { Kto udzielił Pani wsparcia bezpośrednio } \\
\text { po postawieniu rozpoznania? (możliwość } \\
\text { wyboru kilku odpowiedzi) }\end{array}$ & pielęgniarka & 59 & 25,6 \\
& przyjaciele & & \\
& znajomi & 40 & 17,3 \\
& psycholog & 20 & 8,6 \\
& brak wsparcia & 6 & 2,8 \\
\hline Od kogo uzyskuje Pani największe & od rodziny & 7 & 3 \\
\hline & od przyjaciół & 135 & 58,3 \\
& & 52 & 22,5
\end{tabular}


wsparcie emocjonalne? (możliwość

wyboru kilku odpowiedzi)

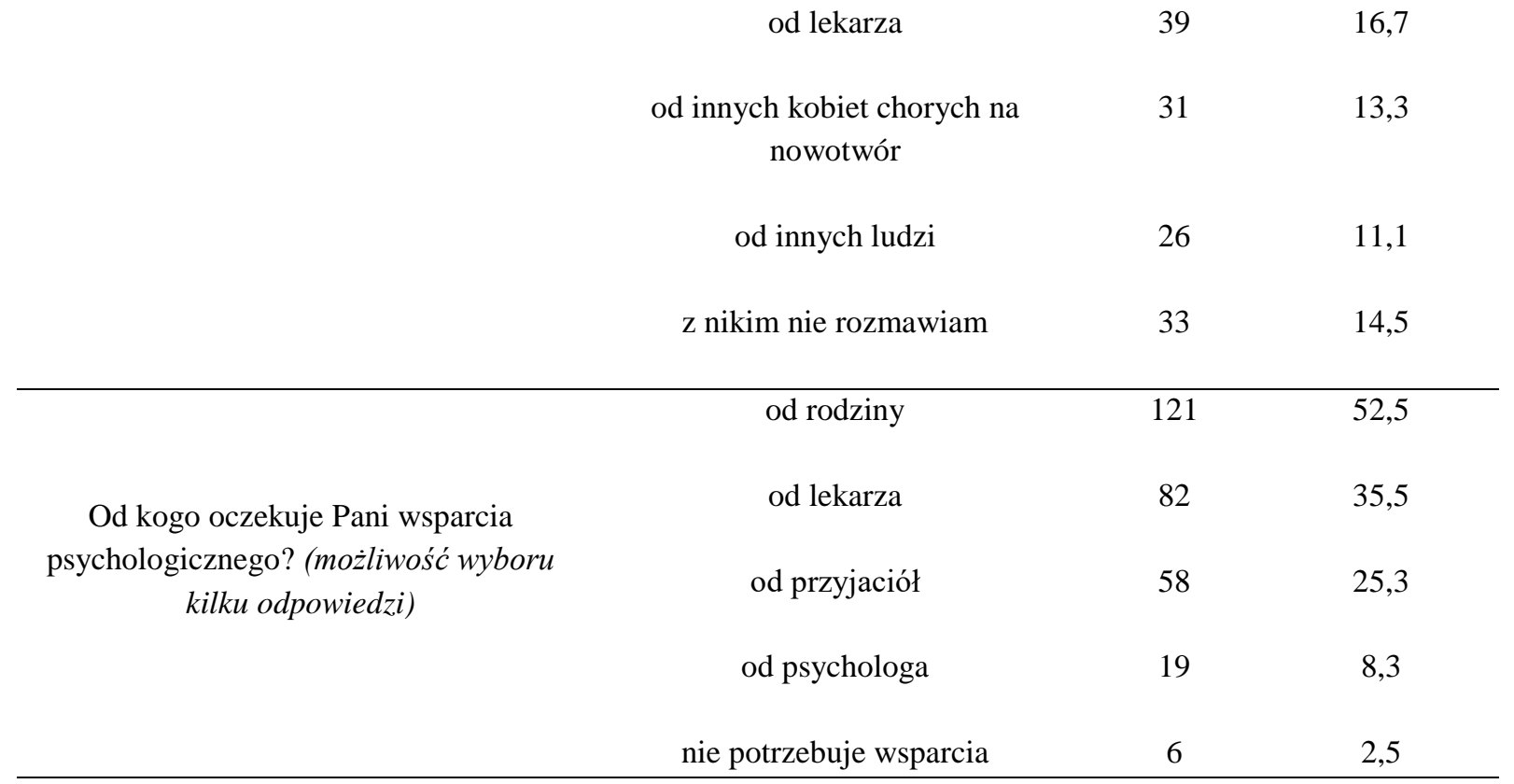

Również w późniejszym czasie, w trakcie trwania choroby, kobiety podkreślały rolę rodziny $(58,3 \%)$, przyjaciół $(22,5 \%)$ oraz lekarza $(16,7 \%)$ w zakresie wsparcia emocjonalnego. Ponadto badane respondentki wskazywały również na to, że wsparcie takie uzyskiwały od kobiet chorych na nowotwór $(13,3 \%)$ oraz innych ludzi $(11,1 \%)$. Zaznaczyć należy, że $14,5 \% \mathrm{z}$ nikim nie rozmawiała na temat choroby i nie uzyskiwała wsparcia emocjonalnego (tab.2).

Kobiety $\mathrm{z}$ rozpoznanym nowotworem piersi $\mathrm{w}$ największym stopniu oczekiwały wsparcia psychologicznego od rodziny (52,5\%), lekarza (35,5\%) i przyjaciół $(25,3 \%)$. Tylko 8,3\% badanych wskazała psychologa, który mógłby udzielić im takiego wsparcia. W badanej grupie 2,5\% kobiet nie oczekiwało żadnej pomocy psychologicznej (tab.2).

Przeprowadzone badania pokazały, że informacje na temat raka piersi respondentki otrzymywały głównie od lekarza specjalisty $(65,4 \%)$. Znaczącym źródłem informacji o chorobie był również internet $(28,7 \%)$, inne chore na raka piersi $(23,1 \%)$ oraz pielęgniarki $(22,5 \%)$. Niewielki odsetek badanych kobiet czerpał informacje na temat raka $\mathrm{z}$ literatury medycznej (12,7\%), stowarzyszeń i fundacji $(5,9 \%)$ oraz z telewizji $(5,2 \%)$ (ryc. 11$)$. 


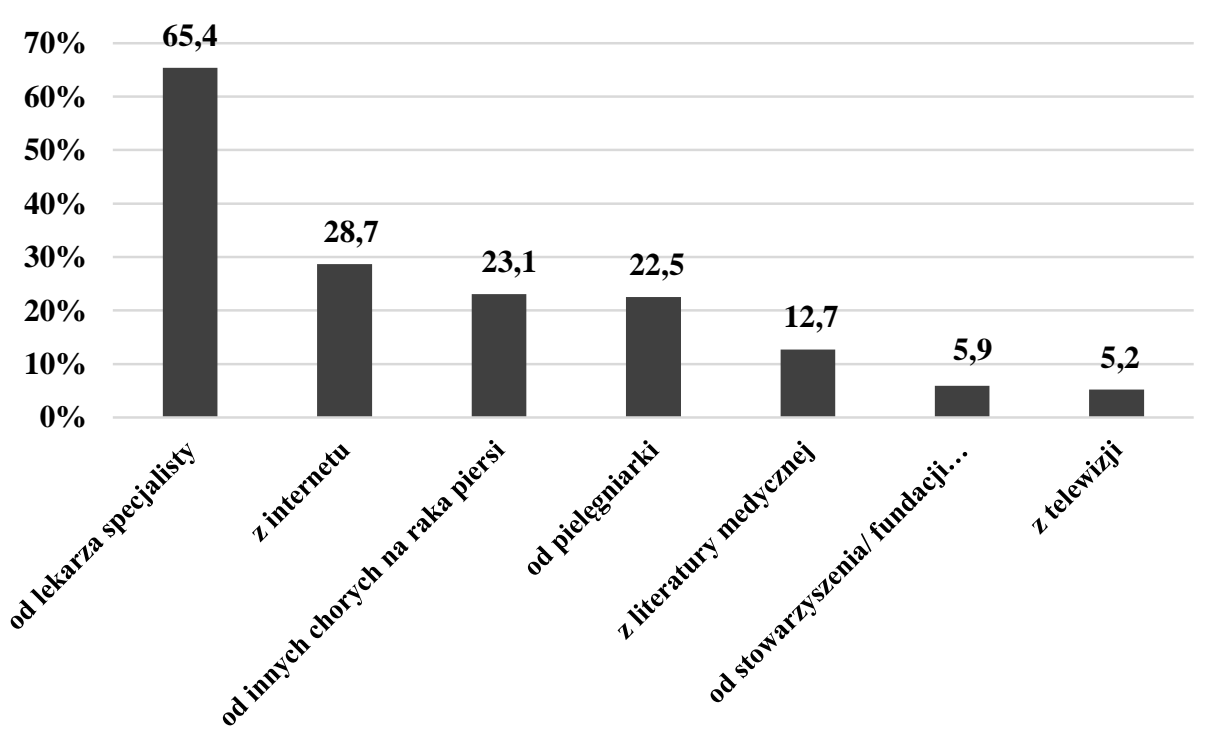

Ryc. 8. Źródła informacji na temat choroby nowotworowej wskazane przez kobiety z rozpoznanym rakiem piersi (możliwość wyboru kilku odpowiedzi).

\section{Dyskusja.}

Jakość życia to pojęcie subiektywne i oceniane $\mathrm{z}$ perspektywy chorego. Aktualne podejście do leczenia onkologicznego, w tym chorych na raka piersi koncertuje się na zastosowaniu skutecznych metod terapii, przy jednoczesnym zapewnieniu wysokiej jakości życia. Poznanie czynników determinujących jakość życia kobiet z rakiem piersi może wskazać kierunki do podjęcia określonych działań, celem zapewnienia pacjentkom odpowiedniego komfortu życia [12-15]. W badaniach własnych prawie połowa respondentek określiła swój stan emocjonalny jako zły lub raczej zły. Podkreślić należy, że ponad 1/3 badanych kobiet wskazała na częste odczuwanie smutku i apatii, z tym, że 6,8\% kobiet odczuwało je codziennie, a u 26,9\% występowały one bardzo często. Tylko 7,7\% kobiet nie odczuwało smutku z powodu choroby, 35,8\% kobiet rzadko miało takie uczucia, a 22,8\% respondentek miało trudności z określeniem czy występują u nich smutek i apatia. Częstość wystąpienia stanów depresyjnych u kobiet $\mathrm{z}$ rakiem piersi waha się w różnych badaniach $\mathrm{i}$ populacjach od $1 \%$ do $50 \%$, a ich nasilenie jest najwyższe w ciągu pierwszych 6 do 12 miesięcy po rozpoznaniu choroby. Jak pokazują badania u kobiet $\mathrm{z}$ rakiem piersi wzrasta ryzyko depresji. $Z$ tego względu wydaje się konieczne zaplanowanie środków zapobiegawczych i terapeutycznych w celu poprawy zdrowia psychicznego i jakości życia pacjentek dotkniętych rakiem piersi [16]. W literaturze stwierdza się, że stany depresyjne i zaburzenie funkcjonowania emocjonalnego związane są między innymi z: młodym wiekiem, brakiem wsparcia ze strony najbliższych oraz obniżonym statusem ekonomicznym. Zburzenia funkcjonowania emocjonalnego, wyrażane poprzez smutek, apatię, obniżony nastrój czy brak nadziei na pokonanie choroby zmniejszą motywację do rozpoczęcia lub kontynowania długotrwałego i wyczerpującego leczenia onkologicznego. Ignorowanie stanu emocjonalnego pacjentek może spowodować, że zastosowane leczenie nie będzie efektywne, co w efekcie może doprowadzić do pogorszenia stanu zdrowia pacjentek [17]. 
W badaniach przeprowadzonych $\mathrm{w}$ ośrodku brzozowskim kobiety na pytanie czego najbardziej obawiają się $\mathrm{W}$ związku $\mathrm{z}$ rozpoznanym nowotworem piersi najczęściej wskazywały na przerzuty nowotworu, nawrót choroby oraz wystąpienie bólu. Największe wsparcie podczas choroby badane kobiety otrzymywały od rodziny, przyjaciół oraz lekarza. Przeprowadzone badania wykazały, że kobiety z rakiem piersi oczekują większego wsparcia psychologicznego ze strony lekarza. Na taki wybór odpowiedzi wskazało 35,5\% badanych. Zwraca uwagę niski procent wskazań respondentek dotyczących oczekiwania wsparcia psychologicznego od specjalisty psychologa (8,3\%). Na wsparcie psychiczne przez osoby bliskie mogły również liczyć pacjentki włączone do badań prowadzonych przez Musiał i in. [18]. W badaniach tych respondentki najczęściej wskazywały na otrzymywanie wsparcia ze strony rodziny $(58,6 \%)$, natomiast personel medyczny stanowił wsparcie dla $14,3 \%$ badanych. Przedstawione wyniki są zbieżne z wynikami badań własnych. Na wzrost zapotrzebowania wsparcia ze strony osób bliskich u kobiet chorych na raka piersi wskazuje również Pytka i Spych [19]. Dla pacjentek badanych przez Zabłocką-Żytkę także zasadniczym źródłem oparcia była rodzina [20].

Według badanych najistotniejsze ograniczenia życia codziennego w związku z pojawieniem się choroby nowotworowej dotyczyły zburzenia prawidłowego funkcjonowania ich życia rodzinnego i towarzyskiego, zmniejszenia efektywności pracy oraz braku możliwości jej kontynuowania. Rozpoznanie raka piersi u kobiety to sytuacja, z którą musi się zmierzyć zarówno chora, jak i jej rodzina. Wystąpienie choroby zaburza prawidłowo funkcjonujące życia rodzinne. Potwierdziły to również badania własne. W szczegółowej ocenie wpływu rozpoznania raka na życie rodzinne $23,1 \%$ badanych stwierdziło, że choroba negatywnie oddziaływała na ich życie rodzinne, natomiast 30,9\% kobiet nie potrafiło ocenić czy taki wpływ występował. Dla grupy kobiet stanowiących $28,7 \%$ badanych rozpoznanie nowotworu nie oddziaływało na życie rodzinne, a co ciekawe dla 17,3\% wystąpienie raka znacząco je poprawiło. Lepsza ocena życia rodzinnego przez kobiety podczas choroby może wynikać ze zwiększonego zaangażowania członków rodziny w tę sferę życia. Na skutek pojawienia się trudnej sytuacji często dochodzi do zacieśnienia więzi rodzinnych, co przekłada się na lepsze funkcjonowanie takich rodzin. Ze względu na fakt, iż chore na raka piersi oczekują największego wsparcia ze strony rodziny, prawidłowo funkcjonujące życie rodzinne jest dla nich szczególnie istotne. Coraz częściej, w powiązaniu z oceną jakości życia chorych onkologicznie, zwraca się uwagę na konieczność wsparcia psychologicznego rodzinie pacjentów. Wsparcie takie może wpłynąć na lepsze funkcjonowanie rodziny, co pośrednio wpłynie na jakość życia pacjentek z rozpoznanym nowotworem [21].

Rozpoznanie raka wiąże się $\mathrm{z}$ bardzo dużą dezorientacją i niepewnością chorej, co do przebiegu choroby, leczenia oraz dalszego rokowania. Poziom tych emocji jest zależny od stanu wiedzy pacjentek i posiadanych informacji na temat choroby [22]. W badaniach własnych wykazano, że respondentki najczęściej informacje na temat choroby nowotworowej uzyskiwały od lekarza specjalisty, z internetu, od innych chorych na raka piersi oraz od pielęgniarki. Mniej znaczące źródło informacji stanowiła literatura medyczna, stowarzyszenia i fundacje oraz telewizja. Podobne wyniki w tym zakresie uzyskali inni badacze [23]. Wyniki tych badań wskazują, że najbardziej zaufanym źródłem informacji na temat choroby jest lekarz. Ponadto Shea-Budgell i wsp. (2014) podali, że pacjenci najchętniej oczekują na informacje spersonalizowane i w formie pisemnej [23]. 
Postawa pacjentki wobec choroby oraz sposób w jaki radzi sobie ze stresem jest szczególnie ważna dla jakości życia i efektu leczenia. Niezwykle istotne znaczenie ma wsparcie chorej i zastosowanie szeroko rozumianej rehabilitacji, ułatwiającej życie w nowych warunkach. Pacjentki z chorobą nowotworową piersi po zakończeniu leczenia szpitalnego powinny zostać pod stałą opieką medyczną, ale również psychologiczną. W tym okresie duże znaczenie powinna mieć rehabilitacja psychofizyczna, będąca integralną częścią całościowej terapii.

\section{Wnioski.}

1. Stan emocjonalny prawie połowy badanych był zły, a jedna trzecia respondentek odczuwała smutek i apatię, co wskazuje na silną potrzebę objęcia kobiet profesjonalnym wsparciem na każdym etapie leczenia.

2. Rozpoznanie raka piersi oraz jego skutki wpływają na stan psychiczny kobiet. Pacjentki w związku z rozpoznanym nowotworem złośliwym piersi najczęściej obawiały się przerzutów nowotworu, nawrotu choroby oraz wystąpienia bólu.

3. Jako ograniczenia życia codziennego wynikające $\mathrm{z}$ choroby kobiety w większości uznawały zakłócenia $\mathrm{w}$ życiu rodzinnym i towarzyskim oraz zmniejszenie efektywności pracy.

4. Największe wsparcie podczas choroby badane kobiety otrzymywały od rodziny, przyjaciół oraz lekarza. Ponadto respondentki z rakiem piersi oczekują większego wsparcia ze strony lekarza, co może stanowić podstawę do wprowadzenia zmian w kształceniu studentów medycyny i prowadzenia szkolenia podyplomowego w tym zakresie.

\section{Piśmiennictwo}

1. Global Cancer Obserwatory, dostęp z dnia 15.11.2021.

2. Iacoviello L., Bonaccio M., de Gaetano G., Donati M.B. Epidemiology of breast cancer, a paradigm of the "common soil" hypothesis. Semin Cancer Biol. 2021;72:4-10.

3. Budny A., Starosławska E., Budny B., Wójcik R., Hys M., Kozłowski P., Budny W., Brodzik A., Burdan F. Epidemiology and diagnosis of breast cancer. Polski Merkur Lek. 2019;46(275):195-204.

4. Didkowska J, Wojciechowska U. Nowotwory piersi w Polsce i Europie - populacyjny punkt widzenia [Breast cancer in Poland and Europe - population and statistics]. NOWOTWORY Journal of Oncology. 2013;63:111-118.

5. Kyranou M, Paul S.M, Dunn L.B, Puntillo K., Aouizerat B.E, Abrams G., Hamolsky D., West C., Neuhaus J., Cooper B., Miaskowski C. Differences in depression, anxiety, and quality of life between women with and without breast pain prior to breast cancer surgery. Eur J Oncol Nurs. 2013;17:190-195.

6. Muzzatti B., Bomben F., Flaiban C., Piccinin M., Annunziata M.A. Quality of life and psychological distress during cancer: A prospective observational study involving young breast cancer female patients. BMC Cancer. 2020;20: https://doi.org/10.1186/s12885-02007272-8. 
7. Gómez-Campelo P., Bragado-Álvarez C., Hernández-Lloreda M.J. Psychological distress in women with breast and gynecological cancer treated with radical surgery. Psychooncology. 2014;23:459-66.

8. Mazurek E. Amazońskie dylematy. Powody rezygnacji kobiet po chirurgicznym leczeniu raka piersi z zabiegu rekonstrukcji piersi. Psychoonkologia. 2014;3:97-105.

9. Yfantis A., Intas G., Tolia M., Nikolaou M., Tsoukalas N., Lymperi M., Kyrgias G., Zografos G., Kontos M. Health-related quality of life of young women with breast cancer. Review of the literature. J BUON. 2018;23:1-6.

10. Duprez C.C., Vanlemmens L., Untas A., Antoine P., Lesur A., Loustalot C., Guillemet A., Leclercq M., Segura C., Lefeuvre-Plesse C., Simon H., Frenel J.S., Christophe V. Emotional distress and subjective impact of the disease in young women with breast ancer and their spouses. Future Oncol. 2017;13: 2667-2680.

11. Shouman A.E., Abou E.N., Gado N., Mahmoud A., Goda I. Quality of life in breast cancer sufferers. Int J Health Care Qual Assure. 2016; 29:721-732.

12. Mokhatri-Hesari P., Montazeri A. Health-related quality of life in breast cancer patients: review of reviews from 2008 to 2018. Health Qual Life Outcomes .2020; 18:338, https://doi.org/10.1186/s12955-020-01591-x.

13. Ho P. J, Gernaat S.A.M., Hartman M., Verkooijen H.M. Health-related quality of life in Asian patients with breast cancer: a systematic review. BMJ Open. 2018; 8(4): e020512.

14. Park B.W., Lee S., Lee A.R., Lee K.H, Hwang S.Y. Quality of life differences between younger and older breast cancer patients. J Breast Cancer 2011;14:112-118.

15. Lee E.S., Lee M.K., Kim S.H, et Ro J.S., Kang H.S., Kim S.W., Lee K.S., Yun Y.H. Health-related quality of life in survivors with breast cancer 1 year after diagnosis compared with the general population: a prospective cohort study. Ann Surg 2011;253:101-108.

16. Jafari A., Goudarzian A.H., Nesami M.B. Depression in Women with Breast Cancer: A Systematic Review of Cross-Sectional Studies in Iran. Asian Pac J Cancer Prev. 2018;19:1-7. doi:10.22034/APJCP.2018.19.1.1.

17. Triberti S., Savioni L., Sebri V., Pravettoni G. eHealth for improving quality of life in breast cancer patients: A systematic review. Cancer Treatm. Rev. 2019;74:1-14.

18. Musiał Z., Sendecka W., Zalewska-Puchała J. Jakość życia kobiet po mastektomii. Probl Pielęg. 2013;21: 38-46.

19. Pytka D., Spych M. Jakość życia pacjentek po zabiegu mastektomii. J Publ Health Nurs Med Rescue. 2012;4:42-49.

20. Zabłocka-Żytka L. Zapotrzebowanie na wsparcie wśród kobiet po leczeniu chirurgicznym z powodu nowotworu piersi. Jakiego wsparcia i od kogo oczekują pacjentki? [The need of social support among women after surgical treatment for breast cancer. What kind of support do patients expect? From whom do they expect?]. Psychoonkologia. 2018;22(2): 50-62.

21. Woźniak K., Iżycki D. Cancer: a family at risk. Prz Menopauzalny. 2014;13(4):253-261.

22. Kugbey N., Meyer-Weitz A., Asante K.O. Access to health information, health literacy and health-related quality of life among women living with breast cancer: Depression and anxiety as mediators. Patient Educ Couns. 2019;102(7):1357-1363.

23. Shea-Budgell M.A., Kostaras X., Myhill K.P. i Hagen N.A. Information needs and sources of information for patients during cancer follow-up”. Curr Oncol. 2014;21:165-173. 